UDK: 28-17:004.738.5

Izvorni naučni rad

Dr. sc. Hakija Kanurić, docent

Univerzitet u Bihaću

Islamski pedagoški fakultet

hakijak@hotmail.com

\title{
SAVREMENA SREDSTVA KOMUNIKACIJE - BLAGODAT I ISKUŠENJE
}

\section{Sažetak}

Uz sve koristi koje internet pruža i opasnosti koje nosi, jasno je da je internet test imana $i$ morala čovjeka, pa $i$ njegovog razuma. Da bi se ovo sredstvo upotrijebilo na ispravan način i da bismo se zaštitili i sačuvali opasnosti koje ono nosi, nužno je aktivnosti na internetu uskladiti sa principima islama. Kroz ovaj rad ukazat ćemo, Allahovom dozvolom, na najbitnije norme islamske etike koje se tiču upotrebe interneta, kao sto su pravila u pogledu vijesti $i$ informacija, adabi dijaloga $i$ vodenja rasprave, čuvanje pogleda, svijest $o$ Allahovom nadzoru, opasnost gubljenja vremena $i$ sl.

Ključne riječi: Internet, društvene mreže, informacije, rasprava, ovisnost o internetu, gubljenje vremena, šejtanske stope, čuvanje pogleda.

\section{Uvod}

Zahvala Allahu, Gospodaru svjetova. Neka su salavati i selami na Allahovog miljenika, odabranog roba i poslanika Muhammeda, njegovu porodicu, ashabe i sve koji slijede njegovu uputu.

Svako vrijeme ima svoja prepoznatljiva obilježja, koja neminovno ostavljaju trag na životu ljudi tog vremena. Stoga, kada želimo upoznati i razumjeti život i djelo neke ličnosti iz prošlosti, nužno je osvrnuti se na obilježja vremena u kojem je živjela, jer stanje društva, poput mira i rata, oskudice i izobilja, običaja i navika, ostavlja upečatljiv trag na društvo u cjelosti, ali i na svakog pojedinca.

Svjetska mreža podataka - internet, uveliko je obilježila ovo naše doba. Ta mreža skratila je udaljenost, povezala ljude i nekadašnju fantaziju pretvorila $u$ stvarnost. Internet se začeo i razvio u zadnjoj trećini 
dvadesetog vijeka. Devedesetih godina postaje dostupan široj javnosti i od tada je u stalnoj ekspanziji. Danas u svijetu internet koristi blizu polovine svjetske populacije, oko 3,5 milijardi ljudi i taj se broj, iz dana u dan, konstantno povećava. ${ }^{1}$

Internet pruža čovječanstvu ogromne usluge, ali istovremeno u sebi krije i mnoge opasnosti. Putem interneta pratimo dešavanja u cijelom svijetu, kao što su ratovi i nemiri, proslave, sportske aktivnosti, upoznajemo daleke i strane kulture i običaje; mogu se pratiti znanstvena istraživanja i dostignuća, mogu se konsultovati stručnjaci iz raznih oblasti; realizuju se bankovne usluge, vrše se novčane transakcije, internet je idealan za marketing i kupoprodaju. Putem interneta i društvenih mreža ostvaruju se komunikacije sa osobama koje poznajemo i koje ne poznajemo, ma gdje se nalazili, što nam pruža mogućnost da razmjenjujemo mišljenja i iskustva. Putem interneta dolazimo do korisnih informacija o običnim životnim potrebama, kao naprimjer kako popraviti kvar na automobilu, kako pripremiti neko jelo, kako riješiti određeni matematički zadatak, kako prepoznati simptome bolesti, kako se liječiti i sl. Gotovo da nam ništa ne može na um pasti, a da o tome već nije nešto kazano na internetu.

To su samo neke od brojnih usluga koje pruža ova mreža i svi mi je svakodnevno, više ili manje, koristimo. Naravno, postoji i druga strana medalje, jer ova mreža nosi brojne opasnosti i negativnosti: internet je idealno sredstvo za širenje i promociju zabluda svih boja i vrsta. Putem ove mreže unose se sumnje u vjeru, promoviraju se ideologije zabludjelih sekti, javno i otvoreno se poziva bludu, nemoralu i mnogim devijacijama koje su oprečne vjeri, moralu i zdravoj ljudskoj prirodi. Sve to plasira se na perfidan način, koji očarava, zavodi i truje djecu, omladinu, pa i odrasle, uništava čednost, navodi na šejtanski put i podstiče na razne morbidnosti i nastranosti. Internet se koristi u svrhu seksualnog zlostavljanja, prijetnji i ucjena, naročito kod mlađih i adolescenata. Internet $i$ društvene mreže pospješuju širenje glasina $i$ izmišljotina. Putem interneta narušava se privatnost $i$ intima špijuniranjem i hakiranjem privatnih računa. Internet nudi razne forme i oblike kocke i klađenja, veliki je uzročnik gubljenja vremena i

${ }^{1}$ http://balkans.aljazeera.net/vijesti/ove-godine-35-milijardi-korisnika-interneta. 18.01. 2018. 
zapostavljanja nekih vjerskih obaveza, kao što je namaz. Internet je odgovoran za nastanak nove savremene bolesti: hronične ovisnosti o internetu, koja uzrokuje duševne i tjelesne tegobe, rezultira zapostavljanjem stvarnog života i problemima u porodici i društvu. Kapije hajra i dobra koje ovo sredstvo pruža širom su otvorene, a isto tako i kapije zla. Nekog će ovo sredstvo uzdići i uzvisiti, a druge će baciti u provalije poniženja. Zbog te realnosti razuman čovjek, koji vodi računa o svojoj vjeri, zastat će pred ovom pojavom i preispitati svoje postupke. Isto tako, roditelji koji se brinu o svojoj djeci i porodici, prosvjetni radnici, vjerski službenici, kao i svi savjesni aktivisti koji prate i usmjeravaju društvo i vode računa o stanju zajednice, dužni su dati svoj doprinos da se potencijali i mogućnosti ove mreže iskoriste $u$ pozitivne svrhe, i da se razvije svijest o opasnostima koje u sebi nosi i kako ih se sačuvati i od njih zaštititi. U nastavku slijedi osvrt na neke islamske principe, koje je pri upotrebi interneta i društvenih mreža, iznimno bitno poznavati i naravno primjenjivati.

\section{Provjera informacija}

Jedna od posebnosti interneta jeste da pruža izuzetno velike količine informacija. Međutim, unos tih informacija dostupan je apsolutno svima, tako da informacije plasiraju ljudi svih mogućih profila: stručni, nestručni, učeni, neuki, čestiti, pokvareni... Ta činjenica nalaže nam selektivnost pri uzimanju informacija, te da prihvatamo i smatramo istinitim samo one informacije koje dolaze iz poznatih i pouzdanih izvora. Na ovo pravilo ukazuje kur'anski ajet u kojem Uzvišeni Allah kaže: "O vjernici, ako vam nekakav nepošten čovjek donese kakvu vijest, dobro je provjerite, da u neznanju nekome zlo ne učinite, pa da se zbog onoga što ste učinili pokajete."2

Čak i kada informacija dođe iz pouzdanog izvora i potvrdi se njena autentičnost, za ispravan sud o njoj nužno je poznavati detalje i okolnosti koje se za nju vezuju, da bismo imali potpunu sliku o dotičnom događaju, jer zanemarivanje okolnosti doprinijet će pogrešnom razumijevanju. Na osnovu okolnosti u kojima se nešto desi, mi ćemo dotični postupak prihvatiti i odobriti ili osuditi i odbaciti. Naprimjer, ako čovjek s kojim smo dogovorili važan sastanak ne dođe

\footnotetext{
${ }^{2}$ El-Hudžurat, 6.
} 
u dogovoreno vrijeme i ne obavijesti nas o svom nedolasku, činjenica je da nije ispoštovao dogovor, ali na osnovu toga nije ispravno donijeti sud o njemu sve dok ne saznamo okolnosti u kojima se to desilo. Ako nije došao, naprimjer zbog udesa ili hitne neodložive situacije u kojoj se našao, odobrit ćemo njegov postupak, a ako nije došao pravdajući se da je prespavao, zaboravio i sl., njegov postupak ćemo osuditi. Kao primjer može poslužiti i slučaj iz života Allahovog Poslanika, s.a.v.s., kada je jedne noći pratio svoju suprugu Safijju iz džamije, pa su ga vidjela dvojica ashaba koji požuriše udaljavajući se od njega, međutim, Poslanik, s.a.v.s., dozva ih i reče: "Polahko, vas dvojica! Ovo je Safijja (moja supruga)."3 Da je jedan od dvojice ashaba kasnije rekao da je vidio Poslanika, s.a.v.s., sa ženom u mrkloj noći, rekao bi istinu, ali istinu koja je nedorečena, jer nisu iznesene sve okolnosti i detalji tog događaja, i nije iznesena činjenica da je dotična žena ustvari supruga Allahovog Poslanika, što će u potpunosti promijeniti sud o ovom događaju.

\section{Ne žuri sa prenošenjem vijesti}

Allahov Poslanik, s.a.v.s., govorio je: "Dovoljno je čovjeku laži da kazuje sve što čuje."4 Nakon što se informacija provjeri, upoznaju se okolnosti i dobije se potpuna slika o njoj, ne smijemo žuriti sa njenim širenjem. Oprez pri širenju informacija pokazatelj je čovjekovog uma, njegove pronicljivosti, imana i vjere. Nikada se vijesti nisu tako brzo i lahko širile kao što je slučaj u našem vremenu, stoga je jako bitno imati na umu upozorenja koja je Poslanik, s.a.v.s., izrekao o opasnosti govora i jezika. Jedno takvo upozorenje prenio je Ebu Hurejra, radijallahu anhu, kazavši da je Poslanik, s.a.v.s., rekao: "Doista čovjek izgovori riječ, ne razmišljajući o njenom značenju, pa zbog nje propada u Vatri dublje od razdaljine između istoka i zapada." 5

${ }^{3}$ El-Buhari - Muhammed bin Ismail, Sahihul-Buhari (Buharijeva zbirka hadisa), Daruš-Šuab, Kairo, 1987. g., br. 3107, i Muslim bin el-Hadždžadž en-Nejsaburi, Sahihu Muslim (Muslimova zbirka hadisa), Daru ihjait-turasil-arabi, Bejrut, bez godine izdanja, br. 2175.

${ }^{4}$ Muslim, br. 5.

${ }^{5}$ Muslim, br. 2290. 
U drugoj, podužoj predaji navodi se da je Poslanik, s.a.v.s., upozorio Muaza b. Džebela, radijallahu anhu, da čuva jezik i da ga obuzda, a Muaz upita: "Allahov Poslaniče, zar ćemo biti pitani za ono što govorimo", na što mu Poslanik, s.a.v.s., reče: "Majka te nemala, Muaze, a zar će ljude naglavačke (na nosovima) u Vatru baciti išta drugo do žetve njihovih jezika!" 6

U spomenutim predajama Poslanik, s.a.v.s., upozorava na opasnost govora i jezika, dok se na društvenim mrežama pretežno komunicira putem tastature, u pisanoj formi, tj. rukom, a ne jezikom, međutim, suština je ista, pa je i propis identičan. Zanimljivo je spomenuti da je Poslanik, s.a.v.s., u jednom hadisu istovremeno upozorio na jezik $\mathrm{i}$ ruku: "Musliman je onaj od čijeg su jezika i ruku mirni drugi muslimani!"7 Zato, prije nego što podijeliš kakvu vijest, provjeri da li je korisno da se ta vijest širi ili ne. Ako se time afirmiraju pozitivne vrijednosti, plemenit moral, podstiče na dobro, ukazuje na zlo, promoviše korisno znanje i sl., proslijedi je, a ako je suprotno tome, ne budi učesnik u njenom širenju.

Isto tako, ako se radi o vijesti kojom se narušava čast nekog muslimana, ne dozvoli sebi luksuz da učestvuješ u njenom širenju, i za vjernika pronađi lijepo mišljenje, ako je to ikako moguće. Kaže Svevišnji Allah: "Zašto, čim ste to čuli, nisu vjernici i vjernice jedni o drugima dobro pomislili i rekli: 'Ovo je očita potvora!',8

Oprez u širenju vijesti naročito je važan kada se radi o stvarima od općeg značaja za zajednicu muslimana. Uzvišeni Allah, upozoravajući na opasnost širenja takvih glasina, kaže: "Kada saznaju za nešto važno, a tiče se sigurnosti ili opasnosti, oni to razglase. A da se oni s tim obrate Poslaniku ili predstavnicima svojim, saznali bi od njih ono što žele saznati. A da nije Allahove dobrote prema vama i milosti Njegove, i vi biste, osim malo vas, sigurno, šejtana slijedili." "Abdurrahman es-Sa' di, rahimehullah, u komentaru ovog ajeta kaže: “Ovako Allah odgaja Svoje

\footnotetext{
${ }^{6}$ Ahmed b. Hanbel eš-Šejbani, El-Musned, Muessesetu Kurtuba, Kairo, br. 22016, i Tirmizi - Muhammed b. 'Isa Ebu 'Isa, Al-Džamius-sahih - sunenut-Tirmizi, Daru ihjait-turasil-arabi, Bejrut, br. 2616. Tirmizi kaže da je hadis hasen-sahih.

${ }^{7}$ Buhari, br. 10, i Muslim, br. 41.

${ }^{8}$ En-Nur, 12.

${ }^{9}$ En-Nisa, 83.
} 
robove, ukazujući na njihov neprimjeren postupak i na to da trebaju, kada se suočavaju sa bitnim pitanjima od općeg interesa, a tiču se sigurnosti i prosperiteta vjernika ili nedaće, da dobro provjere i da ne požuruju sa širenjem takve vijesti. Takvu vijest trebaju izložiti Poslaniku i svojim vođama, onima koji su pronicljivi, učeni, iskreni, razumni i iskusni, koji poznaju suštine stvari i znaju u čemu se ogleda korist, a u čemu šteta. Ako takvi donesu procjenu da je u širenju te vijesti interes i korist vjernicima, da im to donosi radost $i$ štiti ih od neprijatelja, to će učiniti, a ako uoče da u tome nije korist, ili u tome ima koristi ali su negativne posljedice veće, neće tu vijest širiti...

U ajetu se, također, osuđuje i zabranjuje brzopletost u širenju vijesti, neposredno nakon što se čuju, i naređuje se da se promisli prije nego što se progovori, i da se razmotri da li je u tome korist pa da se čovjek u to upusti ili je u tome šteta pa da se suzdrži."10

\section{Govori lijepo!}

Svevišnji Allah poručuje Svojim robovima: "Reci robovima Mojim da govore samo lijepe riječi: jer bi šejtan mogao posijati neprijateljstvo među njima, šejtan je, doista, čovjekov otvoreni neprijatelj."11 Kada želimo postaviti kakav status, poslati poruku na nekoj grupi, dati komentar i sl., imajmo na umu ovaj ajet i prije nego što pošaljemo tekst, razmislimo da li je naš govor lijep. Razmislimo da li time nekog vrijeđamo, da li time diramo nečije osjećaje, da li se time bude sumnje ili rađa neprijateljstvo i mržnja među ljudima. Ako naš govor ima ovakvih elemenata, znajmo da nije lijep, i da je selamet u tome da ga obrišemo. Ako pak tragaš za najljepšim govorom, pa Allah nam opisuje taj govor i kaže: "A ko govori ljepše od onoga koji poziva Allahu..."12 tj. niko ne govori ljepše od onoga ko Allahu poziva. Neka nam ovi ajeti budu vodilja u našem govoru, bilo to uživo ili putem savremenih sredstava komunikacije.

\footnotetext{
${ }^{10}$ Es-Sadi - Abdurrahman b. Nasir b. Abdullah, Tejsirul-Kerimir-Rahmani fi tefsiri kelamil-Mennani, Valorizacija: Abdurrahman b. Mualla el-Luvejhik, Muesseseturrisale, Rijad, 2000.g., str. 190.

${ }^{11}$ El-Isra, 53.

12 Fussilet, 33.
} 


\section{Etika rasprave na društvenim mrežama}

Neslaganje i razilaženje u mišljenju sasvim je prirodno. Različiti, suprotni stavovi i nesuglasice mogu se prevazilaziti na razne načine, a najefikasniji metod jeste razgovor. U našem vremenu društvene mreže u tome igraju veliku ulogu, međutim, nerijetko su one poprište žestokih rasprava i debata, koje često prelaze granice prihvatljivog dijaloga i prerastaju u vrijeđanje, svađe $i$ verbalne ratove širokih razmjera.

Rasprava podrazumijeva pobijanje dokaza dokazom s ciljem da se oponent porazi i potvrdi neispravnost njegove tvrdnje i stava.

Osvrnemo li se na Allahovu knjigu - časni Kur'an, uočit ćemo da se u nekim ajetima pohvalno govori o raspravi, dok drugi ajeti raspravu osuđuju i zabranjuju. To znači da rasprava može biti pohvalna, ali isto tako i zabranjena. Imam Zehebi u svom djelu Veliki grijesi spominje raspravu i kaže: "Ako se rasprava vodi da bi se prepoznala istina $\mathrm{i}$ potvrdila - to je pohvalna rasprava, a ako se rasprava vodi da bi se istina odbila ili se vodi bez znanja - to je pokuđena rasprava. Prema ovoj podjeli, shvataju se ajeti i hadisi o dozvoljenosti i pokuđenosti rasprave."13

\section{Pokuđena rasprava}

To je svaka rasprava kojom se podržava neistina i zabluda ili onemogućava da se ispolji i razjasni istina, ili rasprava koja se odvija bez znanja i dokaza. Takvu raspravu prate vrijeđanje, potcjenjivanje, prepirka, temelji se na pretpostavkama, neosnovanom preferiranju vlastitog stava, a cilj učesnika u takvoj raspravi jeste istaknuti se, uzdići se i degradirati sagovornika. Onaj ko vodi takvu raspravu, pristrasan je i neobjektivan, nije u stanju odreći se svog stava iako ga pobijaju jasni argumenti. Želja mu je ušutkati oponenta, obezvrijediti i osporiti njegov govor, predstaviti ga kao neznalicu, a istaknuti svoju superiornost, inteligenciju, naobrazbu i elokventnost.

Ovakva je rasprava teška bolest i zlo koje pospješuje neprijateljstvo i međusobnu netrpeljivost. Izbjeći ovakvu raspravu znači biti pošteđen mnogih neugodnosti. Onom ko ostavi takvu raspravu, iako zastupa

${ }^{13}$ Ez-Zehebi - ড̌amsud-din b. Ahmed, El-Kebair, Darun-nedvetil-džedide, Bejrut, str. 221. 
ispravan stav, Allahov Poslanik, s.a.v.s., obećao je kuću u Džennetu. Prenosi se od Ebu Umame, radijallahu anhu, da je Poslanik, s.a.v.s., rekao: "Ja garantiram kuću u perivoju Dženneta onome ko ostavi raspravu (el-mira') pa makar bio u pravu, kuću u sredini Dženneta ko ostavi laganje pa makar i u šali, i kuću u najvišem dijelu Dženneta onome ko uljepša svoj ahlak." 14

Svevišnji Allah u dva kur'anska ajeta opisao je pokuđenu raspravu: “A nevjernici se raspravljaju, služeći se neistinama, da bi time opovrgli Istinu, i rugaju se dokazima Mojim i Mojim opomenama."15 „Eto tako Allah ostavlja u zabludi svakoga ko u zlu pretjeruje i sumnja, one koji o Allahovim znamenjima raspravljaju, iako im nikakav dokaz nije došao, pa izazivaju još veću Allahovu mržnju i mržnju vjernika."16 Hatib el-Bagdadi kaže: "U ova dva ajeta Svevišnji Allah ukazao je na pokuđenu raspravu i stavio nam na znanje da je to rasprava bez argumenta i rasprava kojom se širi zabluda i opovrgava istina. Prema tome, pod pokuđenom raspravom podarzumijeva se rasprava bez znanja i rasprava uz razdor, svađu i obmanu, kojom se podstiče zabluda i neistina nakon što se istina ispolji i razjasni."17 Temeljni uzrok vođenja ovakvih rasprava jeste oholost i zadivljenost sobom. Kaže Uzvišeni Allah: "Oni koji o Allahovim znamenjima raspravljaju, iako im nikakav dokaz nije došao, u srcima njihovim je samo oholost koja ih neće dovesti do cilja željenog"18 Iz oholosti se rađaju druge ružne osobine, kao što je želja za isticanjem i demonstriranjem superiornosti nad drugima i sklonost ka uznemiravanju drugih i otkrivanju njihovih nedostataka.

\section{Pohvalna rasprava}

Pohvalna je ona rasprava koja potpomaže istinu i njoj vodi, uz čist i iskren nijet, i koja se odvija na ispravan način. Postoji rasprava koja je

\footnotetext{
${ }^{14}$ Ebu Davud - Sulejman b. El-Eš'as es-Sidžistani Ebu Davud, Sunenu Ebi Davud, Darul-fikr, Bejrut, br. 4800. Hadis je hasen prema ocjeni Albanija.

15 El-Kehf, 56.

${ }^{16}$ El-Mu'min, 34-35.

${ }^{17}$ El-Hatib el-Bagdadi - Ahmed b. Ali, El-Fekihu vel-mutefekkih, valorizacija: Adil b. Jusuf el-Garrazi, Daru-bnul-Dževzi, Rijad, 1421 h., 1/556-557.

${ }^{18}$ El-Mu'min, 56.
} 
lijepa, a postoji i još ljepša. Časni Kur'an stavlja nam u obavezu da raspravu vodimo na najljepši način. Kaže Svevišnji Allah: "Na put Gospodara svoga mudro i lijepim savjetom pozivaj i s njima na najljepši način raspravljaj!” 19 „I sa sljedbenicima Knjige raspravljajte na najljepši način, ali ne i sa onima među njima koji su nepravedni" 20 Raspravljati se na najljepši način znači temeljiti raspravu na znanju i jasnom dokazu, uz lijep ahlak i blagost, lijepim riječima, ${ }^{21}$ a cilj ovakve rasprave jeste afirmirati istinu, istaknuti je i uljepšati, a osuditi zabludu i istaći njenu ogavnost, i to najkraćim putem koji tome vodi. Cilj rasprave ne smije biti nadmetanje i želja za isticanjem, nego je cilj pojasniti istinu i uputiti ljude. Takvu raspravu vodili su Allahovi poslanici sa svojim narodima pozivajući ih u vjeru, to je bila praksa istaknutih ashaba i velikana ovog ummeta.

O Nuhovom narodu Svevišnji Allah kaže: “'O Nuhu', rekoše oni, 'ti si želio da se s nama raspravljaš i dugo si se raspravljao. Daj neka se ostvari ono što nam prijetiš, ako istinu govoriš!", 22

Abdullah b. Abbas, radijallahu anhuma, vodio je raspravu sa haridžijama, nakon čega je veliki broj njih ostavio ideju haridžizma. ${ }^{23}$

Imam Šafija govorio je: "Nije se desilo da s nekim razgovaram, a da mi nije bilo svejedno hoće li Allah razjasniti istinu mojim ili njegovim jezikom." 24

\section{Obilježja pohvalne rasprave}

Da bi rasprava dala svoje plodove i rezultate, nužno je da se sagovornici pridržavaju etike i pravila rasprave. Nekoliko veoma bitnih pravila rasprave možemo uzeti iz ajeta u kojima Svevišnji Allah poučava

${ }^{19}$ En-Nahl, 125.

${ }^{20}$ El-Ankebut, 46.

21 Ibnu Kesir - Ismai b. Omer, Tefsirul-Kur'anil-azim, valorizacija: Muhammed Husejn Šemsuddin, Darul-kutubil-ilmijje, Bejrut, 1419 h., 4/526.

${ }^{22} \mathrm{Hud}, 32$.

23 Ahmed, Musned, br. 656, Hakim - Muhammed b. Abdullah en-Nejsaburi, ElMustedrak 'alas-sahihajni, Darul-kutubil-'ilmijje, Bejrut, 1411.h., br. 2657.

${ }^{24}$ El-Gazali - Ebu Hamid Muhammed b. Muhammed, Ihjau ulumid-din, Darul-marife, Bejrut, 1/26. 
Poslanika, s.a.v.s., kako da vodi raspravu sa idolopoklonicima. To su ajeti sure Seba' u kojima Svevišnji Allah kaže: "Upitaj: 'Ko vas opskrbljuje i iz neba i iz zemlje?' - i odgovori: 'Allah! Da li smo onda mi ili vi na Pravome putu, ili u očitoj zabludi?' Reci: 'Vi nećete odgovarati za grijehe koje mi počinimo niti ćemo mi odgovarati za ono što uradite vi.' Reci: 'Gospodar naš će nas sabrati i onda nam pravedno presuditi, On je Sudija Pravedni, Sveznajući.' Reci: 'Pokažite mi one koje smatrate Njemu ravnim!' - Nema ih; postoji samo Allah, Silni i Mudri!" 25

Cilj rasprave jeste inicirati razum da o nečemu razmisli, kako bi došao do ispravnoga zaključka. Pitanje božanstva temeljno je vjersko pitanje, a idolopoklonici su o njemu raspravljali i sumnje iznosili, ali i pored toga časni Kur'an usmjerava nas da i pri takvoj raspravi vodimo računa o etici razgovora i debate, te da se rasprava vodi na najljepši način, jer svrha rasprave jeste da se istina prepozna i prihvati. Spomenuti ajeti ukazuju na nekoliko bitnih pravila i etiku vođenja rasprave, od kojih su:

Prvo: Na početku rasprave potrebno je ukazati na zajedničke tačke oko kojih su obje strane složne, da bi one bile polazište pri raspravi. Time do izražaja dolazi podudarnost i sužava se krug razilaženja, jer kada je krug neslaganja širok, teško je doći do dogovora i zajedničkog stava. $\mathrm{Na}$ početku ovih ajeta Uzvišeni Allah kaže: "Upitaj: 'Ko vas opskrbljuje i iz neba i iz zemlje?' - i odgovori: 'Allah!'” Idolopoklonici, s kojima se vodila ova rasprava, ne spore da je Allah Onaj koji sve opskrbljuje, kao što o tome Kur'an govori: 'Upitaj: 'Ko vas hrani s neba i iz zemlje, čije su djelo sluh i vid, ko stvara živo iz neživog, a pretvara živo u neživo, i ko upravlja svim?' 'Allah!', reći će oni, a ti reci: 'Pa zašto Ga se onda ne bojite?"' 26 S obzirom na to da oponent prihvata i priznaje tu činjenicu, pitanje o tome nije imalo za cilj da se na njega odgovori, nego je cilj istaknuti zajedničku tačku, koja je aksiom za obje strane, pa je naređeno da se to jasno kaže i potvrdi na početku rasprave. Dakle, rasprava treba da se vodi oko precizno određenog pitanja, nakon što se utvrde temelji i osnove, jer ako nema zajedničkih osnova, rasprava je besmislena.

\footnotetext{
25 Seba', 24-27.

${ }^{26}$ Junus, 31.
} 
Drugo: Ne tvrdi kategorično da je tvoje mišljenje ispravno, a mišljenje oponenta pogrešno. Ne reci svom sagovorniku u raspravi, naprimjer: "Dođi da ti objasnim da sam u pravu i da si ti u krivu!", nego mu kaži: "Jedan od nas dvojice je u pravu, a drugi griješi, hajde da o tome popričamo, kako bismo saznali šta je ispravno." Na ovo iz spomenutih ajeta ukazuju riječi: "Da li smo onda mi ili vi na Pravome putu, ili u očitoj zabludi?" Neko od nas, mi ili vi, je na Pravom putu, a drugi su u očitoj zabludi, po ko od nas zastupa istinu, a ko u zabludi? Ovakvu etiku implementirali su islamski pravnici svojom izrekom: "Kada budemo pitani o našem stavu i stavu naših neistomišljenika o praktičnim pitanjima u vjeri, dužni smo odgovoriti da je naš stav ispravan, a greška je moguća, dok je stav našeg oponenta pogrešan, a postoji mogućnost da bude tačan." ${ }^{27}$ Svrha rasprave jeste doći do istine, a ne lična pobjeda, jer prava pobjeda znači otkriti istinu, prepoznati je i prihvatiti.

Treće: Ne nazivaj stav oponenta ništavnim, iako tako vjeruješ, jer cilj rasprave jeste ukazati na istinu i navesti oponenta da je prihvati. Na tom putu neophodno je približiti se sagovorniku i prihvatiti pretpostavku da je tvoj stav možda pogrešan. To će oponentu dati snage da kvalitetno iznese svoje argumente, te kada bude dao sve od sebe da opravda svoj stav i dokaže ništavnost tvog stava, te mu to ne pođe za rukom, ostaje mu samo da se povinuje zdravom argumentu i istini. Pogledajmo kako se u spomenutima ajetima biranim riječima obraća sagovorniku: "Vi nećete odgovarati za grijehe koje mi počinimo niti ćemo mi odgovarati za ono što uradite vi." Naš postupak uvjetno se naziva "grijehom", dok se postupak oponenta naziva "djelom", kako bi se približilo oponentu. Time se stavlja na znanje da je bitno doći do ispravnog suda, a šta će se stvarno nazvati grijehom ili ispravnim postupkom, to će se vidjeti tek na kraju rasprave.

Četvrto: Sagovornik se treba upoznati sa značajem rasprave i opasnošću koju nosi, jer na osnovu rezultata rasprave slijedi praktična primjena, a sagovornik sam snosi posljedice svoje odluke. Radi se o pravom putu ili zabludi, ispravnom ili pogrešnom, a svako će biti pitan o svom ubjeđenju i postupanju po njemu. Na to ukazuju riječi: "Reci:

${ }^{27}$ Ibnu Nudžejm - Zejnuddin b. Ibrahim, El-Ešbahu ven-nezair ala mezhebi Ebi Hanifete en-Numani, Darul-kutubil-ilmijje, Bejrut, 1999. str. 330. 
'Gospodar naš će nas sabrati i onda nam pravedno presuditi, On je Sudija Pravedni, Sveznajući."”

Peto: Omogući sagovorniku da kaže sve što ima i pažljivo ga slušaj sve dok ne završi svoj govor. Tako će kvalitetnije iznijeti svoje argumente i olakšati da se prepozna istina, ako je ona na njegovoj strani, ili će se precizno ustanoviti mjesto njegovog posrtaja, što će omogućiti da se fokusiramo upravo na tu tačku. To je najkraći put, jer onaj ko vodi raspravu s ciljem da dođe do istine poput je ljekara: daje bolesniku priliku da detaljno govori o svom stanju, nadajući se da će dokučiti uzrok bolesti, gdje se krije i kako je nastao. To ima veliki utjecaj na dijagnozu bolesti pa i na samu terapiju. Čak i ako bi ljekar bio u stanju otkriti uzrok bolesti drugom metodom mimo govora, pacijent je duševno smireniji ako mu se dâ prilika da detaljno govori o svojoj bolesti. Allahov Poslanik, s.a.v.s., nije sumnjao da on zastupa istinu, a da su idolopoklonici u zabludi, kao što nije sumnjao da je grijeh prikladan opis za one koji pored Allaha druge obožavaju, međutim, time se želio približiti oponentu i omogućiti mu da kazuje o svom stavu iznoseći sve argumente koje posjeduje: "Reci: 'Pokažite mi one koje smatrate Njemu ravnim!" Pokažite mi, iznesite mi sve svoje argumente, ja ću ih pažljivo saslušati. Ako niste u stanju iznijeti dokaz kojim biste opravdali svoje obožavanje drugih mimo Allaha, hajde onda da prihvatimo ono oko čega smo se na početku složili: da je Allah jedini, koji vlada i svim upravlja, neka On onda isto tako bude jedini koji se obožava, jer nije pravedno da Allah bude jedini koji stvara, opskrbljuje, svim vlada i upravlja, a drugi se mimo Njega obožavaju.

Šesto: Nastoj privući pažnju i zainteresirati sagovornika svim raspoloživim metodama. Jedan od načina podsticanja na razmišljanje jeste zapitkivanje sagovornika, kao što je to dva puta učinjeno u ovoj kratkoj raspravi: "“Da li smo onda mi ili vi na Pravome putu, ili u očitoj zabludi?'... Reci: 'Pokažite mi one koje smatrate Njemu ravnim!'”

Sedmo: Cilj rasprave jeste da se dođe do rezultata, a ne puki dijalog. Ukoliko razgovor ne daje plodove, to je samo gubljenje vremena i put ka raskolu, netrpeljivosti i preziru. Rezultat ove rasprave jeste ništavnost širka i idolatrije i potvrda prava na obožavanje samo Svevišnjem Allahu: "Reci: 'Pokažite mi one koje smatrate Njemu ravnim!" Odgovora nije bilo, te ostaje samo da priznaju, prihvate i kažu: "Nema Njemu ravnih; postoji samo Allah, Silni i Mudri!" 
Nije nužno da na koncu rasprave oponent prizna grešku i prihvati istinu. Bitno je da upozna jasan dokaz i snažan argument. Ako oponent ne prihvati tvoj stav, to ne znači da si poražen u raspravi. Čak i kada onaj ko je u zabludi ostane pri svom stavu, nakon rasprave neće više biti toliko siguran u svom stavu, njegova ubjeđenja će biti poljuljana, a moguće je da nakon nekog vremena prihvati istinu. Naravno, tome se može nadati ukoliko se vodi računa o etici i pravilima rasprave, u protivnom, rasprava će samo raskol povećati.

Kada se radi o raspravama o vjerskim pitanjima naročito je bitno istaći da se u raspravu može upuštati samo onaj ko je za to kompetentan, kako ne bi nanio nepravdu istini, a isto tako kako ne bi pao pod utjecaj sumnji koje oponent iznosi. Stoga, da bi se upustio u raspravu, nije dovoljno to što je istina na tvojoj strani, nego je nužno biti "naoružan" znanjem, razumijevanjem i poznavanjem etike i pravila vođenja rasprave.

\section{Ovisnost o internetu}

Svi mi dobro znamo koliko se na internetu vremena izgubi. Nemali broj korisnika interneta suočava se problemom pretjerane upotrebe interneta, a ponekad stvar ode $\mathrm{i}$ dalje, tako da prerasta $\mathrm{u}$ jednu vrstu ovisnosti. Ovisnost o internetu označava fenomen pretjeranog ili ekstremnog korištenja interneta u tolikoj mjeri da donosi opasnost po zdravlje i remeti normalan životni tok. U narednim redovima je osvrt na uzroke ove pojave, njene simptome i načine prevencije i suzbijanja.

\section{Ko je najviše podložan ovisnosti o internetu?}

Osobe koje se suočavaju problemom pretjerane upotrebe interneta, ili kako se ponekad nazivaju: „ovisnici o internetu“, pretežno su depresivne, nestabilne osobe, koje se obično suočavaju i sa drugim vrstama ovisnosti, poput duhana, alkohola i sl.

Isto tako, osobe koje tragaju za potvrdom u društvu i ostvarenjem psihološko duševnih potreba, koje ne uspijevaju ostvariti u realnom životu. Iza ekrana korisnik interneta u stanju je skriti svoj identitet, životnu dob, struku, izgled, moral i sve drugo što gradi njegov imidž i reputaciju u društvu, stoga neki korisnici interneta, naročito oni koji su usamljeni ili suočeni sa određenim strahom u stvarnom životu, koriste tu mogućnost da govore o svojim najdubljim tajnama, intimnim 
željama, skrivenim osjećajima, što rezultira osjećajem bliskosti i prisnosti. Međutim, vremenom se otkrije i potvrdi ograničenost oslonca na zajednicu bez lica putem koje se želi zadovoljiti potreba za ljubavi, pažnjom i društvom, da bi nakon toga uslijedila još veća frustracija i depresija.

Isto tako, osobe koje su radoznale i imaju veliku želju za saznavanjem i otkrivanjem novog, podložne su ovisnosti o internetu, obzirom da tu nalaze nevjerovatnu količinu informacija i podataka.

Zatim, pretjeranoj upotrebi interneta podložne su osobe koje su opsjednute filmovima, video igricama i sličnim oblicima razonode.

Psiholozi naglašavaju da je ovisnost o internetu periodičan proces, $\mathrm{u}$ smislu da novi korisnici interneta obično bivaju ti koji pretjerano mnogo vremena provode na mreži kao posljedica njihove zadivljenosti tom pojavom i mogućnostima koje pruža, da bi nakon vremena došlo do zasićenja, a potom do jedne uravnoteženosti u upotrebi ovog sredstva. Međutim, nekim korisnicima interneta taj prvi stadij traje jako dugo i potrebno im je mnogo vremena da ga prevaziđu, a neki ga i ne uspijevaju prevazići.

\section{Simptomi ovisnosti o internetu}

Ovisnik o internetu osjeća nervozu kad nije na mreži, razdražen je i nestrpljenjem iščekuje vrijeme kada će se ponovo konektovati.

Ovisnik o internetu gubi osjećaj za vrijeme dok je na mreži. Zanemaruje zadovoljavanje osnovnih životnih potreba, kao što su hrana i spavanje. Ostaje budan dugo u noć, a nakon tjelesne iscrpljenosti predaje se dubokom i dugotrajnom snu. Gubi sposobnosti prirodne konverzacije sa ljudima i svijetom u okolini. Zapostavlja društveni život, porodične i poslovne obaveze.

Od pokazatelja ovisnosti o internetu je izrazito snažno interesovanje za novosti i zbivanja na društvenoj mreži, a pojavljuju se i znakovi nervnih poremećaja, kao što je podrhtavanje ruke ili prsta, povećano znojenje i $\mathrm{sl.}^{28}$

${ }^{28} \mathrm{https} / / /$ hr.wikipedia.org/wiki/Ovisnost_o_Internetu. 23. 01. 2018. 


\section{Liječenje ovisnosti o internetu}

Problematika terapije protiv ove vrste ovisnosti je u tome što potpuna apstinencija nije moguća. Pametni telefoni, računala i drugi elektronički mediji postali su sastavni dio našeg života, pa se stoga kroz terapiju pokušava naučiti kako optimalno i savjesno koristiti internet.

Na početku bitno je da ovisnik shvati da je bolestan kako bi tragao za lijekom i nastajao prevazići krizu. Terapija se primarno bazira na organizaciji vremena i postepenom smanjivanju upotrebe interneta. $U$ tu svrhu spominju se mnogi praktični koraci koje ovisnik o internetu može poduzeti. Kao npr. da upotrebu interneta svede samo na određene dane u sedmici, da planski reducira vrijeme boravka na mreži na određen broj sati. Prije nego što uđe na internet da precizno odredi šta želi uraditi i da za to odredi potrebno vrijeme, ili da na internet uđe prije bitnog termina kako bi time bio vremenski ograničen. Kada se isključi sa mreže da o njoj ne razmišlja. Da se sustegne od posjete portala za koje zna i pretpostavlja da će ga navesti na dugi boravak pored računara. Da uređaje putem kojih koristi internet udalji od sebe koliko je to moguće, naročito u noćnim satima. Da se povuče iz svih grupa na društvenim mrežama za kojima nema potrebe i da prestane pratiti sve one profile koji mu ne donose traženu korist.

Da preispita svoje prioritete i ponovo ih uredi dajući prednost stvarnom životu, kroz aktivnosti na polju profesije, druženja, posjete, sport, hobi i svaki društveno koristan i produktivan rad.

\section{Šapat vjerniku}

Spomenuli smo opće savjete o suzbijanju ovisnosti o internetu, međutim, vjernik ima dodatnu motivaciju da vodi brigu o svom vremenu, jer vjerski izvori na to nedvosmisleno ukazuju. Časni Kur'an na različite načine skreće pažnju na značaj vremena. Jedan od tih načina je Allahovo zaklinje različitim vremenskim intervalima, kao što su noć, zora, jutro, dan. Vjernik se zaklinje samo Allahom, Njegovim lijepim imenima i savršenim svojstvima, jer je zakletva vid veličanja i hvale, a Allah se zaklinje čim hoće od Svojih stvorenja. Međutim, kada se Allah nečim zakune to ukazuje na značaj i važnost onog čime se zakleo. U suri El-Asr Svevišnji Allah kaže: „Tako mi vremena - čovjek, doista, gubi, samo ne oni koji vjeruju i dobra djela čine, i koji jedni drugima 
istinu preporučuju i koji jedni drugima preporučuju strpljenje.“29 Nakon što se Svevišnji Allah zakleo vremenom ukazao je na činjenicu da je čovjek na gubitku, obzirom da prolaskom vremena prolazi i sam čovjek, a oni koji vjeruju, čine dobra djela i jedni drugima preporučuju istinu i strpljenje, oni nisu na gubitku; jer svoje vrijeme ispravno koriste.

Vrijeme je naš najvrjedniji kapital i najdragocjenije što imamo, jer to je dimenzija unutar koje imamo priliku da djelujemo. Vrijednost ove blagodati, kao i drugih, najbolje se vidi kada se izgubi i kad ona nestane. Tako je bolestan čovjek najviše svjestan vrijednost zdravlja, a oni koji su svoje vrijeme potpuno potrošili i tu blagodat izgubili, koji su do kraja svog životnog puta došli, postaju potpuno svjesni vrijednosti vremena. Kaže Uzvišeni Allah opisujući stanje čovjeka, koji o svom vremenu nije računa vodio, kako će kada mu smrtni čas dođe povikati: ,'Gospodaru moj, povrati me da uradim kakvo dobro u onome što sam ostavio!' Nikada! To su riječi koje će on uzalud govoriti - pred njima će prepreka biti sve do dana kada će oživljeni biti. “30 Opisujući stanje džehenemlija Svevišnji Allah kaže: „Oni će u njemu jaukati: 'Gospodaru naš, izbavi nas, činićemo dobra djela, drugačija od onih koja smo činili.' - 'A zar vas nismo ostavili da živite dovoljno dugo da bi onaj koji je trebao razmisliti imao vremena da razmisli, a bio vam je došao i onaj koji opominje? Zato iskusite patnju, nevjernicima nema pomoći!'‘31

Allahov Poslanik, s.a.v.s., ukazivao je na blagodat vremena i ljudski nemar spram te blagodati, rekao je: „Dvije blagodati prema kojima je čovjek posebno nemaran jesu zdravlje i slobodno vrijeme. ${ }^{\text {‘32 }}$ Ibnu Abbas, r.a., kazuje da je Allahov Poslanik, s.a.v.s., savjetovao jednog čovjeka riječima: „Iskoristi pet stvari prije pet: svoju mladost prije starosti, svoje zdravlje prije bolesti, svoje bogatstvo prije siromaštva, svoje slobodno vrijeme prije zauzetosti i svoj život prije smrti." ${ }^{\text {‘3 }} \mathrm{U}$ ovom hadisu posebno je naglašena mladost, jer je to produktivni period između dvije slabosti u životnom ciklusu. Kaže Svevišnji Allah: „Allah

${ }^{29}$ El-Asr, 1-3.

${ }^{30}$ Mu'minun, 99-100.

31 Fatir, 37.

32 Buharija, br. 6412.

${ }^{33}$ Hakim, br. 7846. Hadis je sahih po ocjeni Hakima i Zehebija. 
je Taj koji vas nejakim stvara, i onda vam, poslije nejakosti, snagu daje, a poslije snage iznemoglost i sijede vlasi;““34 Mladost je period života $u$ kojem je posebno bitno ispravno iskoristiti vrijeme, iako je život $u$ cijelosti prostor za rad i djelovanje. Svevišnji Allah nam je stavio u obavezu da se trudimo sve dok Ga ne sretnemo, rekao je: „I sve dok si živ, Gospodaru svome se klanjaj!‘35

Dnevni namazi obavljaju se u precizno određenim vremenima, što samo po sebi navikava vjernika da vodi računa o vremenu. Kaže Svevišnji Allah: „Vjernicima je propisano da u određeno vrijeme molitvu obavljaju. ${ }^{\text {"36 }}$ A Poslanik, s.a.v.s., je na pitanje o Allahu najdražem djelu kazao da je to: „Namaz u njegovom vremenu.“37

Dakle, Svevišnji Allah nas poučava i odgaja da vodimo brigu o vremenu. Ukazao je na važnost i značaj vremena zaklinjući se njime i kazujući nam o tome kako će čovjek, nakon što svoje vrijeme upropasti priželjkivati i tražiti da mu se da prilika, da dobije makar malo vremena, onog vremena koje mi tako jeftino trošimo. S druge strane, Allah nas praktično poučava da vodimo brigu o vremenu kroz pet dnevnih namaza koje nam je u precizno određenim vremenima propisao.

Imajući sve to u vidu, nedopustivo je vjerniku da uništava svoje vrijeme, tu veliku blagodat koja mu je data, u beskorisnom surfanju po internetu, jalovim, besplodnim raspravama, praćenju nekvalitetnih medijskih sadržaja i svemu onom što mu neće donijeti ovosvjetsku niti ahiretsku korist.

Nakon provedenih sati na internetu $u$ dangubi i besposlici nastaje osjećaj bezvoljnosti, potištenosti, tjeskobe u grudima. S druge strane osjećaj sreće, zadovoljstva i širine u prsima stiče se nakon što uradimo nešto korisno i vrijedno. To je dio Allahove nagrade na ovom svijetu, svakom prema njegovoj zasluzi.

\footnotetext{
34 Er-Rum, 54.

35 El-Hidžr, 99.

${ }^{36}$ En-Nisa, 103.

${ }^{37}$ Buharija, br. 527 i Muslim, br. 85.
} 


\section{Slijeđenje šejtanski stopa}

Korisnici interneta dobro znaju da, ma koliko se pazili, svakog časa im pogled može pasti na nedoličan prizor, slike i scene kakve nije dozvoljeno gledati. Nekada je društvo bilo pošteđeno takvih prizora, da bi potom mediji, u početku pomalo a kasnije sve više i više, ubacivali svoje otrove u ljudske duše i srca. Tako su danas posvuda dostupni sadržaji, scene i slike kakvih bi se možda i sam Iblis postidio. Vjernik je dužan preventivno djelovati i učiniti sve što je u njegovoj moći da spriječi pojavu takvih slika na svom ekranu, a ako se one ipak pojave, dužan je skrenuti pogled i ne dozvoliti da mu otrov u srce uđe. Džabir b. Abdullah, r.a., pitao je Allahovog Poslanika, s.a.v.s., o iznenadnom pogledu, tj. kako da postupi kada iznenada, bez namjere ugleda ženu koja mu nije halal, kaže Džabir: „Pa mi je naredio da skrenem pogled.“38, tj. naredio mu je da ne zadržava pogled na njoj, jer prvi pogled nije njegov izbor pa stoga i nije grijeh, ali ako zadrži pogled i u njemu ustraje griješan je. U tom značenju su i riječi Allahovog Poslanika, s.a.v.s., upućene Aliji, r.a.: „Nemoj prvi pogled popratiti drugim, jer tebi pripada prvi, ali ti ne pripada drugi،“39

Oko je prozor srca, te kada se pruži pogled u srcu se rađa želja. Kada čovjek obori pogled, time će obuzdati svoje prohtjeve i želje, a kada pruži pogled i srce će otvoriti put svojim strastima. Kada čovjek nadvlada svoje porive, osjetit će slast veću od one koju bi našao udovoljavajući svojim hirovima i požudama, jer koga prohtjevi nadvladaju biva ponižen i poražen, dok onaj ko njih nadvlada potvrđuje svoju snagu, odlučnost i ponos te uživa u žaru pobjede u toj bitki koju je izvojevao. Svevišnji Allah poziva vjernike, muškarce i žene, da svoje poglede kontrolišu, jer će tako svoju čednost sačuvati i od nemorala se udaljiti: „Reci vjernicima neka obore poglede svoje i neka vode brigu o stidnim mjestima svojim; to im je bolje, jer Allah, uistinu, zna ono što oni rade. A reci vjernicama neka obore poglede svoje i neka vode brigu o stidnim mjestima svojim....“40

\footnotetext{
${ }^{38}$ Bilježi Tirmizi, br. 2700, i kaže: Ovaj hadis je hasen-sahih.

${ }^{39}$ Bilježi Ahmed, br. 22991, Ebu Davud, br. 2149, Tirmizi, br. 2071, hadis je dobrim ocijenio šejh Albani.

${ }^{40}$ En-Nur, 30-31.
} 
Korisnik interneta treba se udaljiti od svega što mu budi strasti i porive, jer strasti koje su u nama usađene su poput baruta, benzina i sličnih zapaljivih materija, ako su daleko od plamena koji bi ih zapalio ostaju stabilne, bezopasne, ali kada se približe vatri, svakog časa mogu planuti i razbuktati se. Takva je i ljudska duša, smirena i bezopasna, ali kada se približi onom što će je uzbuditi, postaje nemirna, te ako se duh iz te boce oslobodi neće se lako obuzdati.

Stepeni harama koje internet pruža su različiti, od običnog pogleda, preko surfanja u potrazi za portalima nedoličnog sadržaja, do direktnog, živog kontakta. Šejtan zavodi čovjeka korak po korak, a svaki sljedeći je teži i veći haram. Kada se jedan grijeh ponavlja i kada se na njemu ustraje na njega čovjek navikne i duša ga zbog tog grijeha prestane koriti, tada šejtan čovjeka navodi na novi, smjeliji korak kojim će još dublje u haram zagaziti, sve dok grijesi ne postanu njegova stvarnost $\mathrm{i}$ svakodnevnica. I tako, korak po korak postepeno se udaljava od Allahove milosti i približava se Njegovoj srdžbi. Zato nas Allah upozorava da ne pratimo šejtanove stope, nego da mu se suprotstavimo već kod prvog koraka, još na početku, jer je tada mnogo lakše. Poput požara, u početku je to obična iskra ili plamečak koji se lahko ugasi, ali kada se vatra rasplamsa i razbukta taško će se ugasiti. Tako je i sa čovjekom, najlakše mu je oduprijeti se šejtanu već kod prvog koraka, a svakim novim korakom u kojem se čovjek pokori svom neprijatelju približio se svom porazu: „I ne idite stopama šejtanovim; on vam je, zaista, neprijatelj otvoreni." ${ }^{\text {"41 }} \mathrm{U}$ ovom ajetu Svevišnji Allah nam zabranjuje da šejtanove stope slijedimo i upozorava nas da nam je šejtan neprijatelj jasni. Razuman čovjek neće vjerovati svom neprijatelju, neće sebe dovoditi u kušnju, niti će u sebe pretjerano siguran biti, ma koliko bio učen i bogobojazan. Onaj ko se nastoji udaljiti od fitne što je moguće više, kad fitni bude izložen, Allah će ga sačuvati i pomoći mu da je prevaziđe. Ali onaj ko ne nastoji od fitne se udaljiti, nego je možda i priželjkuje, u avanture se upušta, taj biva prepušten samom sebi, ostaje bez Allahove pomoći i podrške i na koncu biva poražen i ponižen. Prisjetimo je Jusufa, a.s., nije se oslanjao na svoju bogobojaznost, znanje i čast, nego je bježao od fitne i zaštitu i pomoć od Allaha tražio. Govorio je: ,'Gospodaru moj draža mi je tamnica od ovoga na što me

${ }^{41}$ El-Bekare, 208. 
one navraćaju. I ako Ti ne odvratiš od mene lukavstva njihova, ja mogu prema njima naklonost osjetiti i lahkomislen postati.'“42 Pošto je od fitne bježao, na Allaha se iskreno oslanjao i od Njega pomoć tražio Allah ga je pomogao, od fitne ga sačuvao i preko toga mu halal putem mnogo više podario.

\section{Svijest o Allahovom nadzoru}

Korisnik interneta mora imati na umu jednu činjenicu, a to je da ga Svevišnji Allah prati i nadzire. U svakom trenutku Allah te vidi, čuje, zna za tebe i tvoje postupke. Ma koliko se skrio od očiju ljudi, Allahu ništa skriveno nije: „On zna poglede koji kriomice u ono što je zabranjeno gledaju, a i ono što grudi kriju. "43 Allahovo zadovoljstvo postići će samo onaj ko toga bude svjestan i Allaha se i u tajnosti i na javi bude bojao: „A onome koji je pred dostojanstvom Gospodara svoga strepio i dušu od prohtjeva uzdržao Džennet će boravište biti sigurno." ${ }^{44}$

Nemarnost prema Allahovom nadzoru osobina je licemjera. Oni svoja loša djela od ljudi kriju a što ih Allah promatra to im ne smeta: „Oni se kriju od ljudi, ali se ne mogu sakriti od Allaha. “45 Ma kakva naša djela u tajnosti bila Allah će ih, prije ili kasnije, otkriti i pokazati. Glasoviti islamski učenjak iz šestog hidžretskog stoljeća Ibnul-Dževzi, rahimehullah, kaže: „Razmišljao sam o dokazima koji ukazuju na Istinitog Gospodara Uzvišenog, pa sam ustanovio da ih ima više nego zrnca pijeska. Jadan od najčudnijih dokaza je to da čovjek ponekad skrije neko djelo kojim Allah nije zadovoljan, pa Allah učini da se to djelo otkrije, makar to bilo nakon vremena, pa se o tome govori, iako ljudi to nisu vidjeli. S druge strane, čovjek skrije kakvo dobro djelo, pa se ono ipak ispolji i o njemu svijet počne govoriti čak i više nego što jeste, tako da se ničeg lošeg o tome čovjeku ne mogu sjetiti i spominju

\footnotetext{
42 Jusuf, 33.

${ }^{43}$ El-Mu'min, 19.

${ }^{44}$ En-Nazijat, 40-41.

${ }^{45}$ En-Nisa', 108.
} 
ga samo po lijepom. Sve to, kako bi se znalo da postoji Gospodar koji neće ničije djelo zanemariti. “46

\section{Zaključak}

Da bi ubirali koristi koje internet nudi i sačuvali se opasnosti koje u sebi nosi, nužno je aktivnosti na internetu uskladiti sa principima islama, kao što su: provjera informacija, opreznost pri širenju vijesti, lijep govor, briga o vremenu, ne slijediti šejtanov put $i$ biti svjestan Allahovog nadzora. Bitno je još istaknuti da musliman, ne samo da je dužan sačuvati se zla i negativnosti koje internet u sebi nosi, nego je dužan nastojati da iskoristi potencijale i mogućnosti ovog savremenog sredstva. Velika je šteta ne iskoristiti mogućnosti koje internet pruža, u svim aspektima, a naročito na polju promocije vjere, moralnih vrijednosti, edukacije, usmjeravanja i svega drugog što nas Allahu Uzvišenom približava.

\section{Literatura:}

1. Ahmed b. Hanbel eš-Šejbani, El-Musned, Muessesetu Kurtuba, Kairo.

2. Ebu Davud - Sulejman b. El-Eš'as es-Sidžistani, Sunenu Ebi Davud, Darul-fikr, Bejrut.

3. El-Buhari - Muhammed bin Ismail, Sahihul-Buhari (Buharijeva zbirka hadisa), Daruš-Šuab, Kairo, 1987. g.

4. El-Gazali - Ebu Hamid Muhammed b. Muhammed, Ihjau ulumid-din, Darul-marife, Bejrut.

5. El-Hatib el-Bagdadi - Ahmed b. Ali, El-Fekihu vel-mutefekkih, valorizacija: Adil b. Jusuf el-Garrazi, Daru-bnul-Dževzi, Rijad, 1421 h.

6. Es-Sadi - Abdurrahman b. Nasir b. Abdullah, Tejsirul-KerimirRahmani fi tefsiri kelamil-Mennani, Valorizacija: Abdurrahman b. Mualla el-Luvejhik, Muessesetur-risale, Rijad, prvo izdanje, 2000.g.

7. Et-Tirmizi - Muhammed b. 'Isa Ebu 'Isa, El-Džamius-sahih-SunenutTirmizi, Daru ihjait-turasil-arabi, Bejrut.

8. Ez-Zehebi - Šamsud-din b. Ahmed, El-Kebair, Darun-nedvetildžedide, Bejrut

46 Ibnul-Dževzi - Džemalud-din Ebul-Feredž, Sajdul-Hatir, Darul-kalem, Damask, 2004. str. 67-68. 
9. Hakim - Muhammed b. Abdullah en-Nejsaburi, El-Mustedrak 'alassahihajni, Darul-kutubil-'ilmijje, Bejrut, 1411.h.g.

10. Ibnu Kesir - Ismai b. Omer, Tefsirul-Kur'anil-azim, valorizacija:

Muhammed Husejn Šemsuddin, Darul-Kutubil-ilmijje, Bejrut, 1419 h.

11. Ibnu Nudžejm - Zejnuddin b. Ibrahim, El-Ešbahu ven-nezair ala mezhebi Ebi Hanifete en-Numani, Darul-kutubil-ilmijje, Bejrut, prvo izdanje, 1999.

12. Ibnul-Dževzi - Džemalud-din Ebul-Feredž, Sajdul-Hatir, Darul-kalem, Damask, 2004. str. 67-68.

13. Muslim - bin el-Hadždžadž en-Nejsaburi, Sahihu Muslim(Muslimova zbirka hadisa), Daru ihjait-turasil-arabi, Bejrut, bez godine izdanja.

14. http://balkans.aljazeera.net/vijesti/ove-godine-35-milijardi-korisnikainterneta. 18.01. 2018.

15. https://hr.wikipedia.org/wiki/Ovisnost_o_Internetu. 23. 01. 2018. 
Hakija Kanuric, PhD

Original scientific paper

University of Bihać

Faculty of Islamic Pedagogy

hakijak@hotmail.com

\section{CONTEMPORARY MEANS OF COMMUNICATION-}

\section{A BLESSING AND A TEMPTATION}

\section{Summary}

With all the benefits that the Internet provides and the dangers it carries, it is clear that the Internet is a test of faith and morals of a man, and even his reasoning. In order to use this tool in the right way and in order to protect and preserve ourselves from the dangers it carries, it is essential to align the activities on the Internet with the principles of Islam. Through this paper, we will show, by Allah's permission, the most important norms of Islamic ethics concerning the use of the Internet, such as rules regarding news and information, Adab (Etiquette) of dialogue and discussion, guarding the gaze, awareness of Allah's control, the danger of losing time, etc.

Keywords: Internet, social network, information, discussion, Internet addiction, waste of time, Satanic footsteps, protection of gaze. 


$$
\begin{gathered}
\text { المدرس الدكتور هاكيا كانوريتشة } \\
\text { كلية التربية الإسلامية بهاتش } \\
\text { hakijak@hotmail.com }
\end{gathered}
$$

\section{وسائل الاتصال المعاصرة بين النعمة والمحنة}

\section{الخلاصة}

على الرغم من كل الفوائد التي يقدمها الإنترنت والمخاطر التي يحملها، فإنهاه من

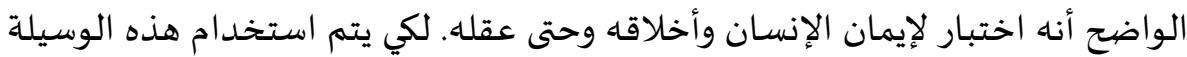

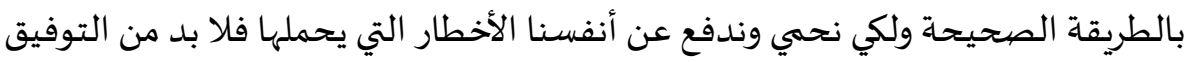

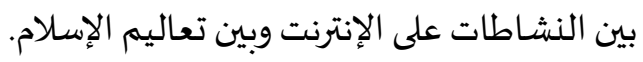

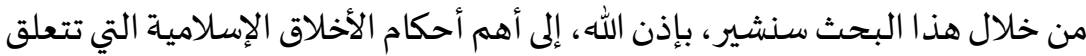

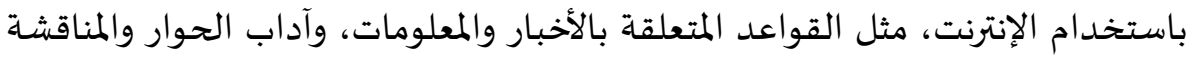
وغض البصر والوعي بمراقبة الله وخطر تضييع الوقت وما شاباه ذلك.

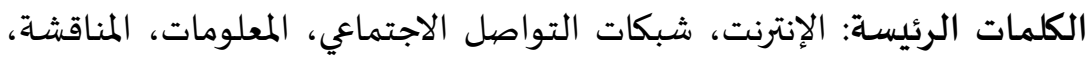

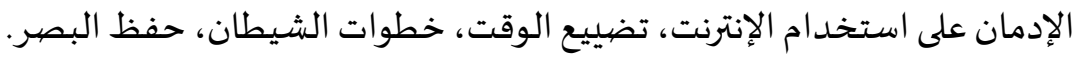

